\title{
REMARKS ON DISCIPLINARY LIABILITY OF A RETIRED JUDGE. SELECTED COMPARATIVE CONSIDERATIONS
}

\section{OBSERVAÇÕES SOBRE A RESPONSABILIDADE DISCIPLINAR DE UM JUIZ APOSENTADO. SELEÇÃO DE CONSIDERAÇÕES COMPARATIVAS}

OBSERVACIONES SOBRE LA RESPONSABILIDAD DISCIPLINAR DE UN JUEZ JUBILADO. SELECCIÓN DE CONSIDERACIONES COMPARATIVAS

\author{
Beata Stępień-Załucka ${ }^{1}$
}

Licença CC BY:

Artigo distribuído sob os termos Creative

Commons, permite

uso e distribuição

irrestrita em qualquer meio desde que o autor credite a fonte original.

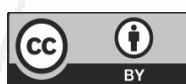

\begin{abstract}
The problems of the judiciary, in some countries, seem to have recently become an important dilemma of constitutional law. One such issue is the issue of retired judges, who at the end of their judicial careers still remain judges, but in a retired state. This raises a wide range of issues, including the proper conduct and behaviour of such judges. Under the rules of many countries in force in this area, such judges are still subject to what is termed disciplinary responsibility and may be held liable for offences committed outside the service, as well as for those committed in the course of the service. The author looks at these solutions and tries to present a model of retired judges' liability.
\end{abstract}

KEYWORDS: Judiciary, retired judges, liability, disciplinary responsibility

$1 \quad$ Dr Beata Stępień-Załucka, adiunkt na Wydziale Prawa i Administracji Uniwersytetu Rzeszowskiego. Autorka kilkudziesięciu publikacji z zakresu prawa konstytucyjnego. Stażystka Mediterranea International Centre for Human Rights Research we Włoszech i Universidad de Las Palmas de Gran Canaria w Hiszpanii. Członek Instituto Iberoamericano de Estudos Jurídicos. Adwokat Izby Adwokackiej w Rzeszowie. Dr in the University of Rzeszów, Poland. beata@kpmz.pl 
RESUMO: Em temos recentes, os problemas do judiciário, em alguns países, parecem ter se tornado um significante dilema de direito constitucional. Um destes problemas é a questão dos juízes aposentados, que ao final de suas carreiras jurídicas seguem como juízes, mas com o status de aposentados. Esta questão levanta uma gama de problemas, incluindo a conduta e o comportamento adequado dos mencionados juízes. Sob as regras vigentes nesta área em muitos países, os juízes aposentados ainda estão sujeitos ao que é chamado de responsabilidade disciplinar, e podem ser considerados responsáveis por ofensas cometidas fora do ambiente de trabalho, assim como por aquelas cometidas em serviço. O autor busca soluções e tenta apresentar um modelo de responsabilidade para juízes aposentados.

PALAVRAS-CHAVE: Judiciário, juízes aposentados, responsabilidade, responsabilidade disciplinar.

RESUMEN: En términos recientes, los problemas del judiciario, en algunos países, parecen haberse vuelto un significante dilema en el derecho constitucional. Uno de estos problemas es la cuestión de los jueces jubilados, que al final de sus carreras jurídicas siguen como jueces, pero con el estatus de jubilados. Esta cuestión levanta una gama de problemas, incluyendo la conducta y el comportamiento adecuado de los mencionados jueces. Sobre las reglas vigentes en esta área, en muchos países, los jueces jubilados todavía están sujetos a lo que se llama responsabilidad disciplinar, y pueden ser considerados responsables por ofensas cometidas fuera del ambiente de trabajo, así como por aquellas cometidas en servicio. El autor busca soluciones e intenta presentar un modelo de responsabilidad para jueces jubilados.

PALABRAS-CLAVE: Judiciario, jueces jubilados, responsabilidad, responsabilidad disciplinar.

\section{ADMINISTRATION OF JUSTICE IS ONE OF THE BASIC TASKS OF} THE JUDICIAL AUTHORITIES.

Currently, the judicial authorities represent a full-grown-up structure of the judiciary, with various courts of varied jurisdiction, in which the offices are held by judges. A judge - as it is often indicated - is one of the legal professions, considered by some to be the highest within the hierarchy of the legal professions, although their organisational role should rather be perceived from the perspective of a civil servant than a profession. Acting as a judge means having the judicial authority at hand, because the activities consist mainly in administering justice. As a model, a judge acts on behalf of the society and is a public official. The legal status of a judge is a combination of professional relationship and official relationship, 
whereas the latter is related to the exercise of the state powers (judicial authority). In their operations judges are independent, and the sole limitation of their actions is imposed by the binding laws. The decisions (judgements) issued by judges may be basically challenged only by way of appeal to a court of a higher instance. The judicial instances are, therefore, a guarantee of the due implementation of the citizens' right of access to court, among other things. It is also important for the very status of a judge, which is related, for example, to one of the attributes of independence of that professional group, namely the impossibility to move a judge to another position.

The current legal regulations applicable to the profession of a judge in the particular countries are included in the acts of law of the highest rank, both international and domestic. Also important are the so called good practices or codes of ethics, which affect the legal status of a judge in the particular countries. Basically, all of the regulations refer to the guarantees enabling proper holding of an office by a judge, and that is to be a guarantee of the citizens' right to court. As to the principle, being a judge - on various continents and in various countries means the necessity of abiding by the same values at work and outside of work ${ }^{2}$.

The lawyers from all over the world have been thinking about how to affect the conduct of judges so that they could fulfil the social expectations by way of their behaviour ${ }^{3}$. Within the current European judicial space, based on dialogue and mutual acceptance of court judgements, the values in the issuing of judgements must comply with certain standards. There is no doubt that the ethical and legal standards of judges conduct are currently affected by the regulation of the Council of Europe and the European Union (particularly the so called soft laws established by the Council of Europe) as well as the adjudications of the European Court of Human Rights and the European Court of Justice.

Improper conduct of a judge, both during the service and outside of it, may lead to removing a judge from their office. The particular legislators apply various solutions in that regard, but it must be explained that the office of a judge is generally so structured in the respective countries that the given person

2 Cf. M. Dakolias, Court Performance Around the World: A Comparative Perspective, Yale Human Rights and Development Journal 1999, No 1, p. 87-142.

3 M. Siwek, Prawa i obowiązki sędziego, Studenckie Zeszyty Naukowe 2006, No 13, p. 37. 
holds the office for a lifetime, regardless of whether they still adjudicate or not. Therefore, particularly in the context of judges who are no longer active in their office, interesting seems to be the problem of their liability for improper conduct, which infringes the interest of the service. The subject will be analysed in this paper.

\section{IF MUST BE NOTED THAT JUDGES - AS TO THE PRINCIPLE - ARE NOT LIABLE FOR THEIR ACTS IN THE SAME WAY OTHER CITIZENS ARE.}

They are subject to disciplinary liability. Disciplinary liability is a legal liability related to repression. This means that disciplinary penalties are imposed which are supposed to be an inconvenience to the penalised person ${ }^{4}$. The inconvenience is not a purpose in itself, because disciplinary liability is to serve the proper performance of public duties by the persons subject to such liability ${ }^{5}$. A breach of legal duties which result from the affiliation to a specific professional group is a reason for being liable, particularly if the respective professional group - in accordance with the statutory provisions - is supposed to perform the public tasks assigned to them ${ }^{6}$. The liability also applies to judges ${ }^{7}$, who as a professional group administering justice are treated by the legislature of most of the democratic countries in a special manner ${ }^{8}$. The disciplinary liability of judges refers mainly to the impairment of the dignity of their office, or other breach of the binding legal order. Such liability results mainly from the high requirements as to the moral standards to be represented by the judges. With their conduct, judges should not breach the law or impair the public trust in the judicial authorities (Article 1 of the Global Code of Ethics for Judges) ${ }^{9}$. Public trust in the judicial authorities as well as the moral respect for and integrity of the administration of justice is - as $4 \quad$ P. Skuczyński, Status etyki prawniczej, Warszawa 2010, p. 11.

5 G. Appleby, A. Blackham, The Shadow of the Court: The Growing Imperative to Reform Ethical Regulation of Former judges, International \& Comparative Law Quarterly 2018, No 3, p. 510-511.

6 S. Dumitrache, Some Considerations on Disciplinary Liability Overlapping Criminal Liability, Judicial Tribune 2011, No 2, p. 186 et seq.

7 W. Kozielewicz, Odpowiedzialność dyscyplinarna sędziów, prokuratorów, adwokatów, radców prawnych i notariuszy, Warszawa 2016, p. 128.

8 U. Hochschild, Müssen Richter mit persönlichen Konsequenzen rechnen?, Neue Richter Vereinigung Info 2012, Nr 2, s. 18-20; M. Gleeson, Judging the Judges, Australian Law Journal 1979, Nr 53, p. 330.

9 E. Handsley, Public Confidence in the Judiciary: A Red Herring for the Separation of Judicial Power, Sydney Law Review 1998, No 20, p. 183 et seq. 
Novos Estudos Jurídicos

it seems - the matter of the highest importance in a modern democratic society (see the preamble to the Bangalore Principles of Judicial Conduct) ${ }^{10}$.

In the present times, the issues of the disciplinary liability of judges have already gained a certain tradition and are regulated by legal acts, which is related to the principle of irremovability of judges recognised in democratic states on the constitutional level. As an example, in France the issue is regulated by the Act on the Status of Judges of 1958, in Germany - the Act on Judges of 1972, in the USA - the Judicial Conduct and Disability Act of 1980, in Australia - the Judicial Complaints Act of 2012, in Hungary - the Act No. CLXII of 2011 on the Status and Remuneration of Judges. In Poland the basis for liability is the Act the Law of Organisation of Common Courts of 2001, in reference to the judges of common courts, provincial administrative courts and military courts, the Act on the Supreme Court, in reference to the judges of the Supreme Court and the Supreme Administrative Court, and in the Act on the Status of the Constitutional Court Judges, in reference to the judges of the Constitutional Court. The Polish law does not provide for disciplinary liability in reference to the judges of the Constitutional Court. The other judges, including the retired ones, are subject to disciplinary liability for their offences ${ }^{11}$. Also important in that regard are the soft law acts, which make precise the provisions of the acts ${ }^{12}$ if their legal nature is not explicit.

3. THE DISCIPLINARY LIABILITY OF JUDGES WHO HAVE RETIRED AND ARE NO LONGER ACTIVE IS BASED ON THE ASSUMPTION THAT THEY ARE STILL REMAINING IN SERVICE, ONLY THE NATURE OF THE SERVICE HAS CHANGED AS A RESULT OF THE RETIREMENT. A RETIRED JUDGE MUST STILL ABIDE BY THE RULES APPLICABLE TO THEIR PROFESSIONAL GROUP.

They must remain impeccable ${ }^{13}$, otherwise their negative conduct could impair the good name of the administration of justice and the interest of the

10 G. Appleby, S. Le Mire, Judicial Conduct: Crafting a System that Enhances Institutional Integrity, Melbourne University Law Review 2014, No 38, p. 41 et seq.

11 Cf. J. R. Kubiak, J. Kubiak, Odpowiedzialność dyscyplinarna sędziów, Przegląd Sądowy 1994, No 4, p. 67 et seq.

12 See also G. Weeks, Soft Law and Public Authorities. Remedies and Reform, Oxford-Portland (OR) 2016, p. 97.

13 M. Laskowski, Ustawowe pojęcie „nieskazitelności charakteru”, Prokuratura i Prawo 2008, No 6, p. 53. 
judicial service ${ }^{14}$. It is inconceivable that judges, also the retired ones, grossly breach the law by way of their conduct or commit ethical offences. Particularly the latter context - the ethics - seems to support the need of applying very high moral requirements to retired judges. After all, senior judges should be the persons from whom we may expect the most, as they are supposed to be models for the younger generations ${ }^{15}$.

The catalogue of disciplinary actions applicable to retired judges is not basically different from the catalogue applicable to the active judges. The specific legal provisions refer mainly to the offences in professional service and impairment of the dignity of the office. Legal regulations do not always include separate provisions applicable to the liability of retired judges. In such cases the regulations apply accordingly. To provide a few examples: the provisions of the French act refer to an impairment by a judge of their duties, honour, discretion and dignity of the profession (Article 43 of the French Act on the Status of a Judge) ${ }^{16}$. The German law refers to a beach of professional duties ( $\S \S 38-43$ of the German Act on Judges $)^{17}$. In Hungary, the regulations refer to a breach of professional duties, and the lifestyle which impairs the respect for the administration of justice ( $\S 105$ of the Hungarian Act No. CLXII of 2011 on the Status and Remuneration of Judges). In the American law there is a reference to good behaviour ${ }^{18}$, similarly as in the Australian law, which refers to the conduct of a judge ${ }^{19}$. The Polish law refers to maintaining the dignity of a judge (Article 104.1. of the Law of Organisation of Common Courts, Article 33.2 of the Act on the Status of the Constitutional Court Judges). Such constructed duty to maintain the dignity of a retired judge is a modified duty to avoid anything which could impair the dignity of an active judge. The statutory regulations provide templates in that regard for the respective codes of conducts or good principles, such as the Polish Collection

14 A. Korzeniowska-Lasota, Odpowiedzialność dyscyplinarna sędziego w stanie spoczynku, Studia Warmińskie 2012, No 49, p. 288.

15 L. Da Ros, Judges in the Formation of the Nation-State: Professional Experiences, Academic Background and Geographic Circulation of Members of the Supreme Courts of Brazil and the United States, Brazilian Political Science Review 2010, No 1, p. 102-130.

16 G. Canivet, J. Joly-Hurard, La responsibilite des juges ici et ailleurs, Revue International de Droit Compare 2006, No 4, p. 1054 et seq.

17 O. Kissel, H. Meyer, Gerichtsverfassungsgesetz. Kommentar, München 2015, p. 178.

18 B. Hamm, B. S. Esplin, The Boundaries of "Good Behavior" and Judicial Competence: Exploring Responsibilities and Authority Limitations of Cognitive Specialists in the Regulation of Incapacitated Judges, The Journal of Law, Medicine \& Ethics 2018, No 2, p. 514-520.

19 G. Appleby, A. Blackham, The Shadow of the Court..., p. 509 et seq. 
of Good Ethical Principles for Judges and Associate Judges, a breach of which may be qualified as a disciplinary offence if it is at the same time assessed with regard to the statutory provisions determining the basis and the scope of the disciplinary liability of judges.

Also important for the disciplinary liability is that a retired judge bears disciplinary liability for impairing the dignity of the office at the time they have served actively in the office. Retirement is of no importance with regard to the possibility of a judge being held liable for any acts committed during active service, regardless of the date of disclosing the act or instigating the disciplinary procedure, which is limited basically only with the time-barring of the disciplinary penalty. Such solution in the Polish law results directly from the contents of Article 104.2 of the Law of Organisation of Common Courts, reading that for impairment of the dignity of judge after retirement and impairment of the dignity of the judge office during the service, a retired judge is subject to disciplinary liability.

A disciplinary penalty may be imposed on a judge for an offence of discipline. The catalogue of the penalties must be adjusted to the current professional status of a judge, and refer to the retirement of a judge. Basically, the penalties may differ from the ones imposed on active judges. Indeed, one may not move a retired judge to another position. The catalogue of penalties should be determined in an act of law. The essence of disciplinary liability in the case of judges is that, for example, a permanent termination of the employment relationship against the will of the judge may take place solely based on a disciplinary decision, which is an extremely important guarantee of the independence of judges. Penalties must be specifically determined, and the disciplinary proceedings may not be arbitrary. Otherwise, such solution would interfere with the constitutional principle of independence and irremovability of judges.

Regulations binding in that regard in Poland provide that the following penalties that may be imposed on retired judges for an offence: 1) admonition, 2) reprimand, 3) salary reduction, 4) suspension of salary increase (indexation), 5) deprivation of the right to retirement along with right to salary (Article 104.3 of the Law of Organisation of Common Courts, Article 34.2 of the Act on the Status of the Constitutional Court Judges - the latter, however, does not comprise the 
suspension of salary indexation in the catalogue of penalties). Adjudication of a respective penalty is vested in the disciplinary court, which should maintain the balance between the type of offence and the type of penalty. The scope of penalty depends, of course, on many aspects of the given disciplinary case. It should mainly be related to the gravity of offence subject to disciplinary proceedings lower in the event of a culpable but minor omission in professional activities and higher in the event of the most serious offence, namely committing a punishable illegal act. Worth mentioning is the fact that the penalty of depriving a judge of the right to retirement, which is equivalent to removing a judge from their office, is practically applied to a disciplinary act of a judge which bears the attributes of a wilful offence. Such offence not only disqualifies a judge, from whom an impeccable character is required, but also undermines the trust of the citizens in the administration of justice.

3. A SPECIFIC THING IN THE DISCIPLINARY LIABILITY OF JUDGES, INCLUDING RETIRED JUDGES, IS THAT DISCIPLINARY COURTS FOR JUDGES OPERATE WITHIN THE NATIONAL JUDICIARY STRUCTURES.

In the current state of affairs in Poland, an important role in that regard has been entrusted to the Disciplinary Chamber operating at the Supreme court, which handles the disciplinary cases of the judges of the Supreme Court, the cases resulting from the appeals against the judgements of the disciplinary courts of first instance (and these would be the disciplinary courts at the courts of appeal for the common court judges), or cases related to disciplinary acts which bear the attributes of wilful offences prosecuted by public indictment, or wilful fiscal offences, or cases in which the Supreme Court applies for consideration of a disciplinary matter indicating the offence (Article 110.1 of the Law of Organisation of Common Courts of 2001). It must be added that for military court judges the disciplinary court of first instance would be the disciplinary court at the district military court (Article 39a.1.1 of the Law of Organisation of Military Courts). As regards the administrative court judges, the disciplinary court of both instances (in different membership) is the Supreme Administrative Court (Article 48.1 of the 
Novos Estudos Jurídicos

Law of Organisation of Administrative Courts). On the other hand, a Constitutional Court judge is liable before the same Court (Article 34.1 of the Act on the Status of the Constitutional Court Judges).

It must also be added that a retired judge may be subject to criminal liability. If an act bears the attributes of an offence, the disciplinary court handles the case ex officio with regard to the permit for subjecting a judge to criminal liability. Moreover, the court may issue a decision allowing that a judge is subject to criminal liability, which is a consequence of the judicial immunity (Article 80.1 of the Law of Organisation of Common Courts of 2001) ${ }^{20}$. In that regard, puzzling is the provision of Article 105.1 of the Law of Organisation of Common Courts, which in non-regulated matters does not include a reference to the legal regulations on the immunity of active judges, which may be interpreted as the absence of immunity of retired judges. That would be an unadvisable interpretation, as retired judges are subject to all of the regulations applicable to active judges, which may be applied to the status of a retired judge, including the standards regulating the immunity of judges. The respective duty in that regard results for the legislators from the provisions of the Constitution, reading that a judge may not be subjected to penal liability or imprisoned without a prior consent of the court specified in the act. A judge may not be detained or arrested, except when caught in the act of committing an offence, if the detainment is essential for ensuring the proper course of proceedings. The president of the court having territorial jurisdiction is immediately notified about the detainment, and they may order immediate release of the detained judge (Article 181 of the Constitution) ${ }^{21}$. Undoubtedly, the immunity must also apply after the judge retires from their office. As it has been indicated in the doctrine, that is to protect a judge active in issuing judgements against the anxiety related to the possibility of being harassed in the future with charges outside of the control of a disciplinary court that could verify the legitimacy of the charges. A broad understanding of immunity as regards the time-span, is to prevent the so called chilling effect, i.e. the building of anxiety in a judge which could prevent them from issuing judgement in compliance with the

20 I. Hayduk-Hawrylak, B. Kołecki [in:] I. Hayduk-Hawrylak , B. Kołecki, A. Wlekińska, Prawo o ustroju sądów powszechnych. Komentarz, Warszawa 2015, p. 196.

21 B. Banaszak, Konstytucja Rzeczypospolitej Polskiej. Komentarz, Warszawa 2009, p. 805. 
methods of conduct of judges in a state of law. The very risk of being held liable in the future, without verification of charges by a disciplinary court, may result in such an effect ${ }^{22}$. So the structure of the legal system in which it clearly results from the contents of the legal regulations that a retired judged avails of the immunity must be supported. The regulations must provide that a retired judge may not be detained or subjected to criminal liability without the permit of a competent disciplinary court. This also refers to the judges of the Supreme Court, as the immunity issue has been regulated in a similar manner in the Law of Organisation of Common Courts of 2001 and in Article 55 of the Act on the Supreme Court. It seems, however, essential that the Law of Organisation of Common Courts of 2001 and the Act on the Supreme Court include the same solution as may be found in the provisions of the Act on the Status of the Constitutional Tribunal Judges (Article 37), such that there are no doubts in that regard.

\section{IN THE LIGHT OF THE ABOVE, IT MUST BE EMPHASISED THAT THE DISCIPLINARY LIABILITY OF A JUDGE MAY RESULT IN THEIR LOSS OF OFFICE, ALONG WITH ALL OF THE PRIVILEGES RELATED THERETO.}

The cases of removing judges from their offices are often related to the offences committed by a judge within the service and outside of it. The solutions are based on a paradigm, in accordance with which a judge holding their office must possess specific competencies and predispositions, also of moral nature ${ }^{23}$. A special organisational role of judges in the administration of justice and objective disputes resolution justifies introduction of some solutions in the respective legal systems which differentiate the legal status of judges from that of the regular citizens, including also other legal professions. The special solutions include the means of holding judges liable ${ }^{24}$. Nevertheless, this does not exempt judges from the duty to abide by the legal order, and what is more - in many cases - the

22 Por. K. Szczucki, [in:] Konstytucja RP, t. 2, Komentarz, eds. M. Safjan, L. Bosek, Warszawa 2016, art. 181, Nb. 13, Legalis.

23 J. N. Barr, T. E. Willging, Decentralized Self-Regulation, Accountability, and Judical Independence Under the Federal Judicial Conduct and Disability Act of 1980, University of Pennsylvania Law Review 1993, No 1423, p. et seq.

24 Cf. F. Contini, R. Mohr, Reconciling Independence and Accountability in Judicial Systems, Utrecht Law Review 2007, No 2, p. 26-43. 
Novos Estudos Jurídicos

principles of conduct are stricter by way of establishing certain legal standards which must be complied with by a judge holding an office ${ }^{25}$.

\section{REFERENCES}

Appleby G., Blackham A., The Shadow of the Court: The Growing Imperative to Reform Ethical Regulation of Former judges, International \& Comparative Law Quarterly 2018, No 3.

Appleby G., Le Mire S., Judicial Conduct: Crafting a System that Enhances Institutional Integrity, Melbourne University Law Review 2014, No 38.

Banaszak B., Konstytucja Rzeczypospolitej Polskiej. Komentarz, Warszawa 2009.

Barr J. N., Willging T. E., Decentralized Self-Regulation, Accountability, and Judical Independence Under the Federal Judicial Conduct and Disability Act of 1980, University of Pennsylvania Law Review 1993, No 1423.

Canivet G., Joly-Hurard J., La responsibilite des juges ici et ailleurs, Revue International de Droit Compare 2006, No 4.

Contini F., Mohr R., Reconciling Independence and Accountability in Judicial Systems, Utrecht Law Review 2007, No 2.

Cooke R., Empowerment and Accountability: the Quest for Administrative Justice, Commonwealth Law Bulletin 1992, No 18.

$\mathrm{Da}$ Ros L., Judges in the Formation of the Nation-State: Professional Experiences, Academic Background and Geographic Circulation of Members of the Supreme Courts of Brazil and the United States, Brazilian Political Science Review 2010, No 1.

Dakolias M., Court Performance Around the World: A Comparative Perspective, Yale Human Rights and Development Journal 1999, No 1.

Dumitrache S., Some Considerations on Disciplinary Liability Overlapping Criminal Liability, Judicial Tribune 2011, No 2.

Gleeson M., Judging the Judges, Australian Law Journal 1979, Nr 53, p. 330.

Hamm B., Esplin B. S., The Boundaries of "Good Behavior" and Judicial Competence: Exploring Responsibilities and Authority Limitations of Cognitive Specialists in the Regulation of Incapacitated Judges, The Journal of Law, Medicine \& Ethics 2018, No 2.

25 A. Le Sueur, Developing Mechanisms for Judicial Accountability in the UK, Legal Studies 2004, No 1-2, p.73-98; $R$ Cooke, Empowerment and Accountability: the Quest for Administrative Justice, Commonwealth Law Bulletin 1992 , No 18, p. 1326. 
Handsley E., Public Confidence in the Judiciary: A Red Herring for the Separation of Judicial Power, Sydney Law Review 1998, No 20.

Hayduk-Hawrylak I, Kołecki B. [in:] I. Hayduk-Hawrylak , B. Kołecki, A. Wlekińska, Prawo o ustroju sądów powszechnych. Komentarz, Warszawa 2015.

Hochschild U., Müssen Richter mit persönlichen Konsequenzen rechnen?, Neue Richter Vereinigung Info 2012, Nr 2.

Kissel O., Meyer H., Gerichtsverfassungsgesetz. Kommentar, München 2015.

Korzeniowska-Lasota A., Odpowiedzialność dyscyplinarna sędziego w stanie spoczynku, Studia Warmińskie 2012, No 49.

Kozielewicz W., Odpowiedzialność dyscyplinarna sędziów, prokuratorów, adwokatów, radców prawnych i notariuszy, Warszawa 2016.

Kubiak J. R., Kubiak J., Odpowiedzialność dyscyplinarna sędziów, Przegląd Sądowy 1994, No 4. Laskowski M., Ustawowe pojęcie „nieskazitelności charakteru”, Prokuratura i Prawo 2008, No 6.

Le Sueur A., Developing Mechanisms for Judicial Accountability in the UK, Legal Studies 2004, No 1-2.

Siwek M., Prawa i obowiązki sędziego, Studenckie Zeszyty Naukowe 2006, No 13.

Skuczyński P., Status etyki prawniczej, Warszawa 2010.

Szczucki K., [in:] Konstytucja RP, t. 2, Komentarz, eds. M. Safjan, L. Bosek, Warszawa 2016, art. 181, Nb. 13, Legalis.

Weeks G., Soft Law and Public Authorities. Remedies and Reform, Oxford-Portland (OR) 2016. 